\title{
Type IV Bismuth-Corlette Hilar Cholangiocarcinoma
}

National Cancer Institute

\section{Source}

National Cancer Institute. Iype IV Bismuth-Corlette Hilar Cholangiocarcinoma. NCI

Thesaurus. Code C134741.

Tumor extends into both right and left 2nd-order ducts. (AJCC 8th ed.) 